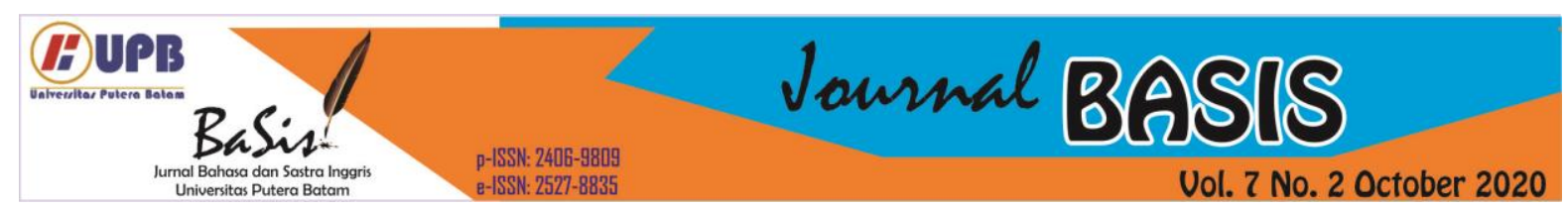

\title{
COMPONENTS OF LOVE IN ASMA NADIA'S NOVEL ASSALAMUALAIKUM BEIJING
}

\author{
Iin Almeina Loebis ${ }^{1}$ \\ Sekolah Tinggi Manajemen Informatika dan Komputer (STMIK) Royal, Kisaran, Indonesia \\ lubisiinalmeina@gmail.com ${ }^{1}$ \\ Fairus Aini Pane ${ }^{2}$ \\ Universitas Islam Sumatera Utara (UISU), Medan, Indonesia \\ fairusainipane@gmail.com²
}

\begin{abstract}
This study was concerned with components of love (Anon n.d.) in Asma Nadia's novel which is entitled Assalamualaikum Beijing (Putri, Kastari, and Ramadhan 2020) The components of love which are analyzed in this study include intimacy, passion, and commitment. The component of love which was called intimacy shown to each other by the main characters of the novel, they are Dewa, Zhongwen and Asma. The component of love called passion was undergone by Dewa and Anita, and this causes the pregnancy of Anita and the cancellation of the marriage party between Dewa and Ra. Zhongwen, one of the main characters of the novel proves his commitment to a girl he loves at the first sight even though it is only about his promise to finish telling a story about Ashima.This research based on what Sternberg's idea about love including intimacy, passion, and commitment. This research mainly focused on love of the main character in the novel based on the theory of love proposed by Sternberg. This study is done by using a qualitative research method (Creswel: 2009:4). This research is completed by the data collection procedure and the data analysis procedure.
\end{abstract}

Keywords : Commitment, Love, Passion

\section{INTRODUCTION}

All human beings who live in this world cannot be separated from a feeling which is called love. Wherever they are in this universe, such a feeling always companies them. They can become closer to each other because of love. Love is the greatest give that God gives to people. Love does not care what other people think about two of you. If you feel depressed and sickly when you are not him or her, that is the indication that you are in love. Love of human beings in various types, and the types of their love depends on the components of the love itself, like intimacy, passion, and commitment. Love is a variety of different feelings, states, and attitudes that ranges from interpersonal affection to pleasure. It can refer to an emotion of a strong attraction and personal attachment. Love can also be a virtue representing human kindness, compassion, and affection "the unselfish loyal and benevolent 
concern for the good of another. It may also describe compassionate and affectionate actions towards other humans, one's self or animals." (Fromm: 1956).Ancient Greek philosophers identified four forms of love: kinship or familiarity (in Greek, storge), friendship (philia), romantic desire (eros), and self-emptying or unconditional love (agape). Modern authors have distinguished further varieties of love: limerence, amour de sai, and courtly love. Non-Western traditions have also distinguished variants or symbioses of these states (Mascara: 2003). Love has additional religious or spiritual meaningnotably in Abrahamic religions. This diversity of uses and meanings combined with the complexity difficult to consistently define, compared to other emotional states.Love in its various forms acts as a major facilitator of interpersonal relationships and, owing to its central psychological importance, is one of the most common themes in the creative arts. Love may be understood as a function to keep human beings together against menaces and to facilitate the continuation of the species (Helen: 2004). Sternberg (1986: 119) claims that the triangular theory of love holds that (Madey and Rodgers 2009) love can be understood in terms of three components that together can be viewed as forming the vertices of a triangle. These three components are intimacy, passion, and decision /commitment. Each of these three terms can be used in many different ways, so it is important at the outset to clarify their meanings in the context of the present theory.

\section{LITERATURE REVIEW}

The first researcher who has ever done a literary research concerning love was Ismawardi Santoso. His literary research was in the form of a thesis entitled Love and Greed in William Shakespeare's The merchant of Venice written in 2012. The focus of the study concerned with love and greed. From the study it was found that one major critical perspective treats the play as a clash between emerging mercantile sensibilities and religious traditions. From this clash the problems of greed emerge but later they are solved by love as a universal mediator.Love conquer all and it was the conclusion of tragic comedy.(Ismawardi 2012)

The second researcher, Hafsah who has ever done a literary research about love.Literary work is in the form of a thesis entitled Negative Impacts of Unrealized Love in Marah Rusli's Siti Nurbaya.This thesis about unrealized love may cause negative effects to the lovers. The negative impacts of the unrealized love can be infidelity revenge, defamation, suffering and death.(Hafsah 2013)

Another references that cpuld be discussed in this part is written by Arianto (2019) about the conflict between two legendary Japanese samurai. Conflicts are presented by showing formulas in popular literature so that readers realize that popular literature cannot be separated from elements of capitalism. Linda \& Arianto (2018) Likewise, it perpetuates a children's story conflict with the presence of a formula that makes a unity of myth a justification because of the producer's greatness in composing the story.

The same research has been done by Trie Utari Dewi with tittle 
Novel Assalamualaikum, Beijing! Asma Nadia's work is a novel with Islamic and romantic nuances published in October 2014. This novel tells the story of a Muslim woman named Asma or Ra who is patient and tough in facing every test she receives. $\mathrm{Ra}$ and Dewa, who had been preparing for marriage, finally failed to get married because it turned out that Dewa had betrayed him by impregnating his partner, Anita. Ra tried to be healthy and courageous in the face of failure in marriage. To forget about the incident, Ra finally accepted the assignment to be a writer in Beijing. He met Zhong Wen, who eventually became a convert because he met with Asma. Suddenly, Asma was given a pretty severe illness test, so she tried to stay away from Zhong Wen by suddenly leaving when they started to love each other together. In the novel Assalamualaikum, Beijing! Asma Nadia's works, many moral messages can be taken learners (Dewi, Sari, and Rahmawati 2019).

The results obtained from research on the novel Assalamualaikum, Beijing are patience in accepting all the trials and trials of life, trying and surrendering to Allah SWT for all the trials of life that are passed, The point of view of this novel is in the third person, The weakness in this novel lies in the plot as well as the naming of characters that confuses the reader, the strength of this novel lies in its plot because it makes the reader curious to continue reading it.

The same research has been done by Susan Neni Triani with tittle " Language Style From the Novel Assallamualaikum Beijing by Asma Nadia. The intrinsic elements of a novel are those that directly contribute to building the story. The combination of various intrinsic elements is what makes a novel tangible. The elements in question are in the form of plot, characterizations, themes, settings, points of view storytelling, message and language or style. Language style can also be defined as how a writer expresses an understanding in words, groups words, and sentences. In other words, style is basically closely related to the way an author presents his ideas. The appearance or expression of these ideas is further manifested in the form of language styles with all their varieties. each author in the work will show the use of language with its own characteristics and patterns differentiate from other authors (Triani, Sunarsih, Mardian, and Rahmawati, 2019).

The same research has been done by Ellif Shiffiyn Khairaa with tittle "The characterization of Margio as the main character in the novel entitled Lelaki Harimau by Eka Kurniawan", This study uses Gerard Genette's narrative structure which focuses on the concept of frequency to analyze characterization.

Qualitative descriptive method is used to reveal and make an in-depth analysis of Margio's characterization. The result of this research is that Margio has a strong characterization and it is he who is connected to other characters in the novel. He is known as a loving person, obedient to parents, and a strong man. The moral value of this novel is the key to family perfection is good communication from each family member. This lesson is important in the way we study the complexity of human relationships, 
especially within families (Khairaa 2020).

Another references that cpuld be discussed in this part is written by Arianto (2019) about the conflict between two legendary Japanese samurai. Conflicts are presented by showing formulas in popular literature so that readers realize that popular literature cannot be separated from elements of capitalism. Linda \& Arianto (2018) Likewise, it perpetuates a children's story conflict with the presence of a formula that makes a unity of myth a justification because of the producer's greatness in composing the story.

\section{RESEARCH METHOD}

Research designs, according to Creswell (2009: 3), are plans and the procedures for research that span the decisions from broad assumptions to detailed methods of data collection and analysis. This plan involves several decisions, and they need not be taken in the order in which they make sense to him and the order of their presentation. The overall decision involves which design should be the worldview assumption the researcher brings to the study; procedures of inquiry (called strategies); and specific methods of data collection, analysis, and interpretation. He adds that there are three types of design. They are qualitative, quantitative, and mixed methods.

The research which is applied in this thesis is in the form of qualitative research method by which a research applies procedures that are made of the use of qualitative data. Creswell (2009: 4) states that qualitative research is a means for exploring and understanding the meaning individuals or groups ascribe to a social or human problem. The process of research involves emerging questions and procedures, data typically collected in the participant's setting, data analysis inductively building from particulars to general themes, and the researcher making interpretations of the meaning of the data.

It is added that, according to Moleong (2009: 6), (Janosik, 2005) qualitative research is research that aims to understand the phenomenon of what is experienced by research subjects, e.g. behavior, perception, motivation, action, etc. holistically and with a form of words in the specific context. Not only does it provide valuable information to certain research questions in its own right but there is a strong case for using it to complement qualitative research methods. Other extreme qualitative research may also help you to understand the findings of quantitative research (Dawson: 2005).

According to Bogdan and Taylor ,Qualitative method is used as research procedures that resulted descriptive data containing of spoken and written words and people behaviour which can be observed. In other words, qualitative research is a research procedure that resulted descriptive data and relies on narrative description.

This research is a qualitative research. It is a language research that needs man as a tool of getting data; it does not deal with number at all. As stated by Bogdan and Biklen (1982: 27) that Qualitative research has the natural setting as the direct source of data and the researcher is the key 
instrument.

\section{Source of Data}

There are two sources that are used in this research. They are primary source and secondary source. The primary source of this research is taken from the novel Assalamualaikum Beijing written by Asma Nadia in 2014, and the secondary data are taken from references including textual books, journals, and internet-handouts which give information about love and its components such as intimacy, passion, and commitment.

\section{Data Collection Procedure}

Before the analysis of the data about love and its components, the writer must collect the data which are needed to be analyzed. The collection of the data, is done through the following procedure:

1. Reading Assalamualaikum Beijing novel, the novel chosen as the primary data, in order to understand the whole story of the novel.

2. Selecting the data or information from the novel which are concerned with love and its components including passion, intimacy, and commitment.

3. Then the data which are all obtained from the primary source are ready to be analyzed.

\section{Data Analysis Procedure}

After the needed data dealing with love and its components such as intimacy, passion, and commitment are collected, the analysis is done through the following process.

1. First, all the data already gained are studied carefully. They are scrutinized in such a way to determine that the data are really concerned with love and its components such as intimacy, passion and commitment.

2. Secondly, some quotations which are related to the matters being discussed are made. They are taken from some pages in the novel to prove that the matters concerning love and its components are really there.

3. Thirdly, the quotations which are made are explained again to clarify the maters in each of the quotations.

4. Finally, the findings from the analysis are made in order that the readers of this study get general description about what have already been analyzed.

\section{RESULT AND DISCUSSION}

Love in this research includes within its purviewed those feelings that given rise, essentially to the experience of warmth in a loving relationship.It was found that there was a component of love, the first was, intimacy,(Misty.K.Hook,Lawrence.Ge rstein, Lacy Detterich 2011) which is used in the novel written above. This component of love describes a very close relationship between the main characters of the novel who fall in love with each other. The main characters of the novel who show their intimacy to each other are Dewa and $\mathrm{Ra}$ and Zhongwen and Asma.

Dewa and $\mathrm{Ra}$ have become intimate friends since a few years ago. 
Dewa has told Ra that he loves her and she accepts his love. She is always happy beside him because he likes to make a joke in front of her. Besides, they always meet each other and tell many things about their relationship.

. It is very possible for them to meet each other they have become the students at the same faculty. They always try to spare their time in order that they can have time to meet each other wherever they want to meet. $\mathrm{Ra}$ even feels that she misses Dewa if she does not meet him even a day. The intimacy of Ra to Dewa can be described through the following quotation:

Saking seringnya, gadis yang awalnya tak perduli, mulai merasa kehilangan ketika satu hari berlalu dan bayangan Dewa tak ditemukan. "Ra?" "Ya?" Keheningan pecah. "Di sini pertama kali Dewa bilang cinta sama Ra." Gadis berwajah mungil di depannya mengangguk. "Dan itu sebabnya, Dewa ingin bilang sesuatu yang sangat penting dalam hidup Dewa." "Hanya dalam hidup kamu?" Setengah menggoda kalimat itu meluncur, Dewa cepat-cepat meralat, "Juga dalam hidup Ra."

(Nadia, 2014: 4) (Asma Nadia 2013)

Because of being very often, the girl who at the beginning did not give her care, started to feel something lost when a day passed and Dewa's shadow was not found. "Ra?" "Ya?" The silence broke. "Here, Dewa firstly said to love Ra." The girl who had a cute face in front of her nodded. "And it is the reason why Dewa wants to say something very important in Dewa's life." "Only in your life?" The sentence slided and half tempted, then Dewa hastily did a correction, "Also in your life, Ra.”(Nadia, 2014, 4)

The above quotation describes the intimate relationship between Dewa and Ra. They are always together day by day and they miss each other if they do not meet each other even in a single day. They even go together to see the place where they for the first time said that they fell in love to each other. The beauty of $\mathrm{Ra}$ always makes Dewa want to be close to her. He does not want to make her disappointed just because of having said something which cannot be accepted Ra. Because he loves her, he always wants to give happiness to her at any time he meets her.

The passion commitment refers to the drives that lead to romance, physical attraction, sexual consummation, and related phenomena in loving relationships. The passion commitment thus includes within its purview those sources of motivational and other form of arousal that lead to the experience of passion in aloving relationship (Emiliya, Menik, dan Lestari, 2019).

Though Dewa has a love relationship with $\mathrm{Ra}$, he is also close to another girl whose name is Anita. She is his friend who works at the same office. She is beautiful so that there are many men who like and fall in love with her. He is lucky because he is liked by her. He is even asked by her to accompany her to go home together. He feels that Ra will not be angry with him if she accidentally sees him accompany her to go home 
together, because he thinks he only regards Anita as his friend.

Because he does not think that he will betray Ra just because of accompanying Anita to her house, he decides to do it without having any burden in his mind. Actually he wants to leave her soon after they arrive at her house; however, the evening wind which blows very hard and which is followed by heavy rain, forces him to stay at her house in a longer time. They spend the time while watching television and drinking coffee made by Anita herself. He cannot deny that the coffee served by her is nice and can warm up his body.

That evening, Anita is alone at her house and she is only accompanied by Dewa who must accidentally stay there because of the heavy rain. Her father and mother are still outside because they have to present the marriage party of their neighbor. She tells him that her parents will come home soon. Then she offers him another glass of coffee and they continue their conversation about some matters from their office. After this, he stands up and is ready to go home but she begs him not to leave her alone. She tells him that recently the situation around her house is not safe because of some robberies.

Actually, Dewa does not feel safe to be at her house together only with her. He is afraid that the neighbors around her house will misunderstand and will be angry with him. However, he has no heart to leave her alone; moreover, it is still raining outside. Therefore, he decides to accompany her until her father and mother arrive at home. When the time is already late at night, he becomes more restless.

It is already one a. $\mathrm{m}$, the time which is morally not good for him to be together with a girl in her house. Again, he wants to go home in a hurry, but realizing that her parents do not arrive yet, he then decides not to leave her. After some minutes, he sees her come out from her bedroom wearing a sleeping dress. It looks thin and smells fragrant. In such a moment, she smiles at him while coming closer to him and bringing a pillow, a blanket, and a bolster. When she comes very close to him, he becomes passionate to her, especially when he looks at the forms of her body. His passion after looking at her body forms can be seen in the following quotation:

"Dewa, kalau capek, aku siapkan kamar, ya , tidur di dalam kamar saja." Lelaki berambut nyaris menyentuh bahu itu cepat-cepat menggeleng. "Kamu, kan belum istirahat juga." Dewa menggeleng lebih tegas. "Um, aku tidur di ruang tamu sini aja, deh." Senyum manis Anita muncul. Gadis itu bangkit, lalu berjalan ke dalam, sebelum kemudian mendekati lelaki itu dengan membawa bantal, guling, dan selimut. Jarak mereka belum pernah sedekat ini sebelumnya. Dia bahkan bisa menghirup harum farfum dari tubuh gadis itu. Dan, siluet yang terbentuk dari cara berpakaian Anita mengusik kelelakiannya. Kedua mata anak muda itu terpana. Anita tersenyum, semakin mendekat. Di luar hujan tercurah kian deras. (Nadia, 2014: 35-36) 
"Dewa, if you are tired, I will prepare a room for you, ok? Just sleep in the room." The man whose hair nearly touched his shoulder hurriedly shook his head. "You don't take a rest yet, do you?" Dewa shook his head more firmly. Úm, I will sleep in this livingroom." Sweet smile of Anita appeared, the girl got up, then she walked inside and later came closer to the man while bringing a pillow, a bolster, and a blanket. The distance between them had never been as close as before. He could even inhale the fragrant parfume from the girl's body. And, the silhouette of Anita's way of wearing dress teased his virility. The two eyes of the man stupefied. Anita smiled and came closer. The rain was very heavy outside. (Nadia, 2014 : 35-36)

In the above quotation, it is clearly described that Dewa has a female friend who works together with him at the same office. She is a beautiful girl whose name is Anita and she always tries to be closer to him. She likes him because he is a handsome man and he wants him to be her lover. She ever asks him to accompany her to go home. She has ever done it twice but soon after he arrived at her house, he asked her permission to leave her.

The decision/commitment component refers to, in the short term, the decision that one loves someone else, and in the long term, the commitment to maintain that love.The decision or commitment componenent thus includes within its the cognitive elements that are involved in decision making about the existence of and potential long term commitment to a loving relationship.Before parting in the bus at the first time, Zhongwen meets Asma. He promises her that he will continue to tell the story about Ashima. To make her sure that he will finish the story about Ashima, he gives her his name card hoping that she can contact him if she wants to meet him or needs his help. She, however, has never called him for some days.

At this present moment, he really wants to meet her. He wants to continue to tell her the end of the story about Ashima. He thinks he must pay his promise to her. He really wants her to know the end of the story. Besides, he has also missed her and wants to meet her as soon as possible. For him, Asma is a girl whose name is nearly the same as Ashima. He even likes to call her Ashima. His commitment that he will finish to tell the story about Ashima can be seen in the quotation below.

Terlalu dini untuk membicarakan kata yang paling sering dikutip banyak manusia itu, sekarang. Lelaki itu merindukan kenyamanan. Dia ingin menyelesaikan kisah yang sudah dimulai, tetapi belum diselesaikannya. Dan, dari begitu kecilnya kesempatan, dunia mempertemukan mereka kembali. Pertanda baik! (Nadia, 2014: 71)

It was too soon to talk about the words which are often quoted by many people, now. The man missed safety. He wanted to finish the story which had been started, but it was not finished 
yet. And, from the very small opportunity, the world united them again. Good sign! (Nadia, 2014: 71)

The above quotation shows that Zhongwen feels that his promise to finish telling the story concerning Ashima is his debt. Therefore, he wants to do it as soon as possible. He realizes that he must meet or find her so that he can do his promise. $\mathrm{He}$ does not want to be regarded as a man who does not keep his promise even though it is only about telling a story. Besides, he really wants to know further about Asma who has made his heart like her.

He then carries his worn-out knapsack and continues his journey. He keeps on looking for her in some restaurants, flea markets, and some other places where he thinks he can find her. He really wants to meet her as soon as possible. He goes on walking along the narrow streets in Beijing and some places in the villages. Though he feels tired, he can finally meets her in front of the mosque named Niujie.

He calls her name and she looks at her. They look happy because they have not met each other for many hours. Then they walk side by side. He tries to control himself in order that he will not be seen to be nervous beside her. Afterwards, he informs her about the history of the mosque, but when she asks him to come into the mosque, he tells her that he would love to, but it is only open to Moslems.

After this meeting, Asma leaves Zhongwen because she returns to her country, Indonesia. Their dialogues continue after Asma is Indonesia. They always talk to each other by means of using some instant messengers, and Zhongwen even sometimes sends a message to her or phones her. Commitment for people who have fallen in love with each other is something that must be proved.(Marc B.levy 1998) If a lover promises something to be given to their lovers, they have to give it to them. If it is not proved, they can, of course, be disappointed because for them commitment can be a measuring rod to know how far someone loves them. Commitment can be said as something which takes up some of your time because of agreement that you have made or responsibilities that you have.

\section{CONCLUSION}

After the analysis of the matters which are concerned with the components of love like intimacy, passion, and commitment found in Asma Nadia's novel entitled Assalamualaikum Beijing, gets some important findings.(Andriani, Hayati, and Nst n.d.) The findings can be seen below. Dewa and Ra are very intimate to each other. They have fallen in love with each other since they study at the same faculty in a university (Tennov 1998). They always meet each other to tell many things that they think important for their love relationship. Their intimacy continues until they make a plan to come to a party. Unfortunately, however, Dewa is trapped by Anita, his female friend from the same office where they work. $\mathrm{He}$ is seduced by her to do a sexual intercourse that effects on her pregnancy. $\mathrm{Ra}$ becomes very disappointed and she does not want to continue their love relation anymore. Zhongwen, someone from China, also falls in love with a beautiful girl 
named Asma who comes from Indonesia. He likes very much to see her and really wants to be closer to her. When he knows that she will be back soon to Indonesia, he exploits his time to talk much to her. He keeps his promise to finish telling the story about Ashima. He even finally tells that he loves her and she accepts his love. Dewa actually loves Ra very much. He even asks her to continue their relationship to a marriage. However, on his way to their marriage, he is templed by a young beautiful girl named Anita, his female friend who works together with him in the same office. After doing the forbidden sexual intercourse, he feels very sorry, but Ra cannot give her forgiveness to him who has already made her disappointed very much.

\section{REFERENCES}

Andriani, Susi, Yenni Hayati, and M. Ismail Nst. n.d. "Nilai-Nilai Islami Dalam Novel Assalamualaikum Beijing."

Anon. n.d. Triangular Theory of Love.

Arianto, T. (2019). The analysis of formula in the legend of japanese samurai rurouni kenshin and miyamoto mushasi: popular literary approach. Jurnal BASIS, 6(1), 55-64. https://doi.org/https://doi.org/10.3388 4/basisupb.v6i1.1047

Asma Nadia. 2013. Assalamualaikum Beijing. Noura Books.

Dewi, Trie Utari, Indah Dwi Novita Sari, and Fanny Rahmawati. 2019. "Kritik Novel Assalamualaikum , Beijing! Karya Asma Nadia Pendekatan Struktural." Jurnal Imajeri 01(2):91100.

Emiliya, Silvia Luxma, Supervisor Menik, and S. Lestari, Remen Pd. 2019. "A PSYCHOLOGICAL MAP OF
LOVE."

Hafsah. 2013. "No Title." Negative Impacts of Unrealized Love in Marah Rusli's Siti Nurbaya.

Ismawardi, Santoso. 2012. "No Title." Love And Greed in William Shakespeare's The Merchant of Venice.

Janosik, Steven M. 2005. "Metode Penelitian Moeloeng." NASPA Journal 42(4):1.

Khairaa, Ellif Shiffiyn. 2020. "The Characterization of Margio in Novel Entitled Lelaki Harimau By Eka Kurniawan." Jurnal Basis 7(1):159.

Linda, L., \& Arianto, T. (2018). Child Literature Genre Formulation in Walt Disney Animation Movie. Jurnal Basis, 5(2), 11. https://doi.org/https://doi.org/1 0.33884/basisupb.v5i2.776

Madey, Scott F., and Lindsey Rodgers. 2009. "The Effect of Attachment and Sternberg's Triangular Theory of Love on Relationship Satisfaction.' Individual Differences Research 7(2):76-84.

Marc B.levy, Keith E. Davis. 1998. "Journal of Social and Personal

Relationships." Journal of Social and Personal Relationships 5:439-71.

Misty.K.Hook,Lawrence H.Gerstein, Lacy Detterich, Betty Gridley. 2011. "Journal of Counseling \& Development." Journal of Counseling and Development 81:462-72.

Putri, Nofa, Silva Kastari, and Syahrul Ramadhan. 2020. 
Vol. 7 No. 2 October 2020

e-ISSN : $2406-9809$ p-ISSN : $2527-8835$

http://ejournal.upbatam.ac.id/index.php/basis

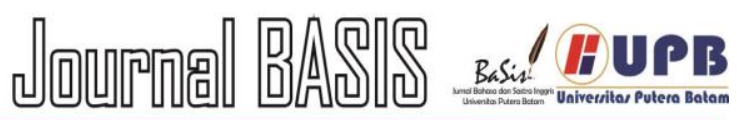

"Assalamualaikum Beijing Karya Asma Nadia Konflik Batin Tokoh Utama Dalam Novel." Bahasa Dan Seni 12(02):200-205.

Tennov, Dorothy. 1998. Love and Limerence:

The Experience of Being in Love Oleh Dorothy Tennov. 2 cetak ul. Lanham, New York: Scarborough house, 1998.

Triani, Susan Neni, Eti Sunarsih, Mardian Mardian, and Desy Rahmawati. 2019. "Gaya Bahasa Novel Assalamualaikum Beijing Karya Asma Nadia (Kajian Stilistika)." JPBSI (Jurnal Pendidikan Bahasa Dan Sastra Indonesia) 4(2):70. 
Vol. 7 No.2 Octaber 2020

e-ISSN : $2406-9809$ p-ISSN : $2527-8835$

http://ejournal.upbatam.ac.id/index.php/basis

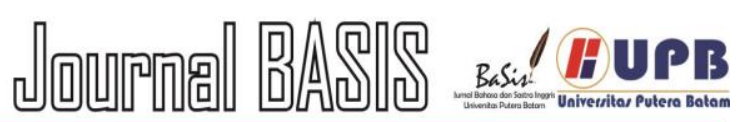

Page | 386 